\title{
Hepatitis B virus DNA in children's liver diseases: detection by blot hybridisation in liver and serum
}

\author{
J SCOTTO, MICHELLE HADCHOUEL, CHRISTIANE HERY, F ALVAREZ, \\ JEANNINE YVART, P TIOLLAIS, O BERNARD, AND C BRECHOT
}

From Unité de Recherche d'Hépatologie Infantile (INSERM U 56), and Clinique de Pédiatrie, Université Paris-Sud, Hôpital d'Enfants, Bicêtre, France, Unité de Recombinaison et Expression Génétique (INSERM U 163), Institut Pasteur, Paris, France, and Service de Médecine Nucléaire, CHU de Bicêtre, Bicêtre, France

SUMMARY Molecular hybridisation using cloned hepatitis B virus DNA (HBV DNA) was applied to liver and serum samples from 46 children ( 39 with liver diseases and seven controls) for detection of HBV DNA sequences, free and integrated into the liver cell genome. HBV DNA integration was observed in 10 children. The young age of some of these cases indicates that such integration can occur early in liver disease and is not related to the duration of viral infection. Thirteen children exhibited serological evidence of active viral multiplication. All but one had free HBV DNA in liver tissue and integrated HBV DNA sequences were found in four cases. Integrated HBV DNA sequences alone were also detected in three children with neither HBV-antigens nor HBV DNA in serum. One had inactive cirrhosis, and the two others, chronic active hepatitis. Consequently DNA hybridisation may be useful for diagnosis, in the absence of serological signs of HBV infection; its specificity was enhanced in the present investigation by negative results in six children with autoimmune chronic active hepatitis. Taken together, the above results imply that HBV-DNA integration can occur in both active and inactive liver disease. Integrated HBV DNA was also observed in the liver of three children with fatal hepatic failure who presented with antibodies to $\mathrm{HBsAg}$ and/or to hepatitis B core antigen in the serum. This finding raises the question of the relationship between the host immune factors and the state of HBV DNA:

Molecular hybridisation using a labelled nucleic acid as probe allows detection of complementary DNA or RNA sequences.

In liver disease, cloned HBV DNA provides such a probe for detecting HBV DNA sequences and for determining the state of viral DNA in the host cell that is, free or integrated into the host genome. The presence of HBV DNA sequences integrated into the cellular DNA was first shown in (1) the tumorous and non-tumorous parts of livers in subjects with hepatocellular carcinoma, ${ }^{12}$ (2) a hepatoma cell line. ${ }^{34}$ and (3) the liver of patients with chronic hepatitis and, in two cases, with acute hepatitis. ${ }^{56}$

Studies of HBV DNA patterns in children with liver diseases could prove useful, because HBV

Address for correspondence: Dr J Scotto. INSERM U 56, Hôpital de Bicêtre, Le Kremlin-Bicêtre. France. F 94270.

Received for publication 18 October 1982 might be related to certain childhood liver diseases of unknown aetiology. Further, studies of the state of HBV DNA at an early stage of infection are important to ascertain the time of possible $\mathrm{HBV}$ DNA integration and to understand the physiopathology of HBV-related liver diseases and the role of integrated HBV DNA sequences.

We therefore applied the blot hybridisation technique to liver samples in order to detect the presence and to study the state of HBV DNA in various childhood liver diseases.

In previous studies concerning adults it has been shown, in cases where the amount of extracted DNA was sufficient to perform various controls, that hybridisation of the high molecular weight DNA after Hind III digestion corresponded to HBV DNA integration into the host genome. ${ }^{56}$ Although, in the present study, the small quantity of DNA obtained from needle biopsies did not allow such controls, our results strongly suggest (1) that 
integration can be an early event in hepatitis B viral infection, (2) that DNA hybridisation is of diagnostic usefulness in patients in whom no serological markers of HBV infection can be detected, and (3) that in cases with fatal hepatic failure the early humoral immune response may be associated with integrated HBV DNA sequences.

\section{Methods}

\section{PATIENTS}

Liver biopsies were obtained from 46 children who were grouped according to their clinical, histological, and serological characteristics at the time of biopsy.

Group I (Table 1) consisted of 15 children with $\mathrm{HBsAg}$ and anti-HBc in their serum. All had chronic hepatitis in varying histological degrees ranging from chronic persistent to chronic aggressive hepatitis.

Group II (Table 2) comprised 24 children with liver disease but without $\mathrm{HBsAg}$ in the serum. Two subgroups were defined: the first (IIa) included 11 children with liver disease which may have been related to HBV: eight of them indeed presented with a history of possible contact with $\mathrm{HBV}$ in the form of anti-HBV antibodies or of a history of past HBs antigenaemia and/or of possible familial contact. We also included in this subgroup three children whose chronic active hepatitis (patient 21) or inactive cirrhosis (patients 23 and 24) may have been owing to HBV despite the lack of evidence for past HBV infection. ${ }^{8}$ The second subgroup (IIb) included 13 patients who presented with one fairly well defined liver disease not so far known to be related to HBV: acute hepatitis A virus infection, chronic active hepatitis with serological markers of autoimmunity (smooth muscle antibodies (SM Ab) or liver kidney microsomal antibodies (LKM Ab)) and cholestasis of various aetiologies.

Group III (Table 3) included seven control children with normal liver or liver dysplasia at histology and without any serological markers.

Liver samples were generally obtained by needle biopsy, sometimes at necropsy (patients 17,27), or by surgical biopsy (patients $1,22,41-46$ ). Tissues were immediately frozen and stored in liquid nitrogen.

\section{SEROLOGICAL INVESTIGATIONS}

Serum samples were collected at the time of the biopsy. Immunological markers of $\mathrm{HBV}$ and hepatitis $\mathrm{A}$ virus infection were tested by radioimmunoassay (Abbott reagents). The autoantibodies SM Ab or LKM Ab were investigated by indirect immunofluorescence.

\section{IMMUNOHISTOLOGICAL METHODS}

Sections of liver tissue, when available, were examined for $\mathrm{HBsAg}$ and $\mathrm{HBcAg}$. We applied indirect immunoperoxidase technique for both antigens and added direct immunofluorescence for $\mathrm{HBcAg}$. The reagents used were rabbit antibody to HBsAg (Behring), peroxidase-labelled sheep Fab anti-rabbit Ig (Institut Pasteur), human antibody to HBcAg (Pr Trepo, Lyon), and peroxidase-labelled sheep antibody antihuman Ig for immunoperoxidase technique. Direct immunofluorescence was performed with human antibody to $\mathrm{HBcAg}$ conjugated with fluorescein isothiocyanate (Pr Trepo, Lyon).

Table 1 Group I: hepatitis B surface antigen-positive children

\begin{tabular}{|c|c|c|c|c|c|c|c|c|c|c|}
\hline \multirow[b]{3}{*}{$\begin{array}{l}\text { Patient } \\
\text { no }\end{array}$} & \multirow[b]{3}{*}{ Age } & \multirow[b]{3}{*}{$\begin{array}{l}\text { Duration } \\
\text { of } \\
\text { disease }\end{array}$} & \multirow[b]{3}{*}{$\begin{array}{l}\text { Liver } \\
\text { histology }\end{array}$} & \multirow{2}{*}{\multicolumn{2}{|c|}{ Serum }} & \multicolumn{5}{|l|}{ Liver } \\
\hline & & & & & & \multicolumn{2}{|c|}{$H B V$ antigens } & \multicolumn{3}{|c|}{$H B V D N A$} \\
\hline & & & & $H B e A g$ & $\begin{array}{l}H B V \\
D N A\end{array}$ & $H B s A g$ & $H B c A g$ & $\begin{array}{l}\text { Inte- } \\
\text { grated }\end{array}$ & Free & $\begin{array}{l}\text { Smear } \\
\text { below } \\
3.2 \mathrm{~Kb}\end{array}$ \\
\hline $1-3$ & $6 y, 8 y, 6 y$ & $19 \mathrm{~m}, 6 \mathrm{y}, 11 \mathrm{~m}$ & $\mathrm{CPH}$ & + & + & + & + & + & + & + \\
\hline $4-10$ & $\begin{array}{l}18 \mathrm{~m}, 6 \mathrm{y}, 3 \mathrm{y}, 5 \mathrm{y}, \\
6 \mathrm{y}, 10 \mathrm{y}, 6 \mathrm{y}\end{array}$ & $\begin{array}{l}9 \mathrm{~m}, 2 \mathrm{y}, 16 \mathrm{~m}, 10 \mathrm{~m} \\
2 \mathrm{y}, 2 \mathrm{y}, 2 \mathrm{y}\end{array}$ & $\mathrm{CPH}$ & + & + & + & + or NT & - & + & + \\
\hline 11 & $12 y$ & $14 \mathrm{~m}$ & CAH & + & + & + & NT & - & + & + \\
\hline 12 & $10 y$ & $15 \mathrm{~m}$ & CAH & + & - & + & + & + & + & - \\
\hline $13^{*}$ & $14 y$ & $5 \mathrm{~m}$ & $\mathrm{CH}$ & + & + & + & + & + & - & - \\
\hline 14 & $29 \mathrm{~m}$ & $15 \mathrm{~m}$ & $\mathrm{CPH}$ & - & - & + & NT & - & - & - \\
\hline 15 & $12 y$ & $2 y$ & $\mathrm{CLH}$ & - & - & + & - & - & - & - \\
\hline
\end{tabular}

$\mathrm{CPH}=$ chronic persistent hepatitis $\mathbf{C A H}=$ chronic aggressive hepatitis; $\mathrm{CH}=$ chronic hepatitis; $\mathrm{CLH}=$ chronic lobular hepatitis; $\mathrm{Kb}=$ kilobase pair; $\mathrm{NT}=$ not tested.

* Child with congenital humoral immune deficiency. Liver histology could not distinguish between persistent and aggressive hepatitis. 
Table 2 Group II: hepatitis B surface antigen-negative children

\begin{tabular}{|c|c|c|c|c|c|c|c|c|c|c|}
\hline \multirow[b]{2}{*}{ Subgroup } & \multirow[b]{2}{*}{$\begin{array}{l}\text { Patient } \\
\text { no }\end{array}$} & \multirow[b]{2}{*}{ Age } & \multirow{2}{*}{$\begin{array}{l}\text { Duration } \\
\text { of } \\
\text { disease }\end{array}$} & \multirow[b]{2}{*}{ Diagnosis } & \multicolumn{4}{|c|}{ Serum in liver } & \multicolumn{2}{|c|}{$H B V D N A$} \\
\hline & & & & & $\begin{array}{l}\text { anti- } \\
H B s\end{array}$ & $\begin{array}{l}\text { anti- } \\
H B C\end{array}$ & $\begin{array}{l}\text { anti- } \\
\mathrm{HBe}\end{array}$ & $\begin{array}{l}H B V \\
D N A\end{array}$ & $\begin{array}{l}\text { Inte- } \\
\text { grated }\end{array}$ & Free \\
\hline \multirow{8}{*}{$\begin{array}{l}\text { Children } \\
\text { with } \\
\text { HBV } \\
\text { context }\end{array}$} & 16 & $15 y$ & $2 m$ & FH & + & + & - & - & + & + \\
\hline & 17 & $5 \mathrm{~m}$ & $2 \mathrm{~m}$ & FH & - & - & + & - & + & - \\
\hline & 18 & $8 y$ & $4 m$ & PHF & - & + & - & - & + & - \\
\hline & 19 & $7 m$ & $7 \mathrm{~m}$ & NPD & - & + & - & - & - & - \\
\hline & 20 & $18 \mathrm{~m}$ & $11 \mathrm{~m}$ & $\mathrm{GCH}^{*}$ & - & - & - & - & - & - \\
\hline & 21,22 & $16 \mathrm{~m}, 11 \mathrm{y}$ & $11 \mathrm{~m}, 17 \mathrm{~m}$ & $\mathrm{CAH}$ & - & - & - & - & + & - \\
\hline & 23 & $16 \mathrm{~m}$ & $14 \mathrm{~m}$ & IC & - & - & - & - & + & - \\
\hline & $24-26$ & $9 y, 9 m, 17 y$ & $3 y, 9 m, 4 m$ & IC & - & - & - & - & - & - \\
\hline \multirow{7}{*}{$\begin{array}{l}\text { Children } \\
\text { without } \\
\text { HBV } \\
\text { context }\end{array}$} & 27,28 & $5 y, 9 y$ & $2 \mathrm{~m}, 2 \mathrm{~m}$ & HA & - & - & - & - & - & - \\
\hline & $29-31$ & $13 y, 11 y, 15 y$ & $9 \mathrm{~m}, 8 \mathrm{y}, 14 \mathrm{~m}$ & AICAH (SMAb) & - & - & - & - & - & - \\
\hline & $32-34$ & $11 y, 3 y, 8 y$ & $7 y, 15 \mathrm{~m}, 5 y$ & AICAH (LKMÁb) & - & - & - & - & - & - \\
\hline & 35,36 & $18 \mathrm{~m}, 15 \mathrm{~m}$ & $18 \mathrm{~m}, 15 \mathrm{~m}$ & EHBA & - & - & - & - & - & - \\
\hline & 37 & $5 \mathrm{~m}$ & $5 \mathrm{~m}$ & IHBA & - & - & - & - & - & - \\
\hline & 38 & $4 y$ & $4 y$ & A1ATD & - & - & - & - & - & - \\
\hline & 39 & $34 m$ & $32 \mathrm{~m}$ & FFC & - & - & - & - & - & - \\
\hline
\end{tabular}

FH = fulminant hepatitis; $\mathrm{PHF}=$ progressive hepatic failure; NPD = Niemann Pick disease $;$ GCH = giant cell hepatitis;

$\mathrm{CAH}=$ chronic active hepatitis; IC = inactive cirrhosis; $\mathrm{HA}=$ hepatitis $\mathrm{A} ; \mathrm{AICAH}=$ autoimmune chronic active hepatitis;

SMAb = smooth muscle antibodies; LKMAb = liver kidney microsomal antibodies; EHBA = extrahepatic biliary atresia;

IHBA $=$ intrahepatic biliary atresia; A1ATD $=$ alpha-1-antitrypsin deficiency; FFC = familial fibrogenic cholestasis; anti-

$\mathrm{HBs}=$ antibody to hepatitis $\mathrm{B}$ surface antigen; anti-HBc = antibody to hepatitis $\mathrm{B}$ core antigen; anti- $\mathrm{HBe}=$ antibody to hepatitis $\mathrm{Be}$ antigen.

* Giant cell hepatitis with autoimmune haemolytic anaemia. ${ }^{7}$

MOLECULAR DNA-DNA HYBRIDISATION

The methods used for molecular hybridisation in serum and liver have already been described. ${ }^{159}$

Briefly, after extraction, liver DNA was digested by Hind III, a restriction endonuclease which cuts cellular DNA at a specific nucleotide sequence but does not cut the HBV DNA so far studied. ${ }^{10}$ The DNA fragments resulting from digestion were separated according to their size by agarose gel electrophoresis and transferred to a nitrocellulose filter according to the Southern technique. ${ }^{11}$ Serum DNA was similarly treated but the digestion step was omitted. Cloned HBV DNA ${ }^{12}$ was labelled by nick-translation ${ }^{13}$ to a specific activity of $3 \times 10^{8}$ to $4 \times 10^{8} \mathrm{cpm} / \mu \mathrm{g}$. Hybridisation was carried out with this probe after denaturation.

Table 3 Group III: control subjects

\begin{tabular}{lll}
\hline $\begin{array}{l}\text { Patient } \\
\text { no }\end{array}$ & Diagnosis & $\begin{array}{l}\text { Liver } \\
\text { histology }\end{array}$ \\
\hline 40,41 & Hepatomegalia & Normal \\
$42-44$ & Extrahepatic portal block & Normal \\
45 & Caroli's disease & Fibrosis \\
46 & Congenital hepatic fibrosis & Fibrosis \\
\hline
\end{tabular}

\section{Results}

A needle biopsy sample (about $20 \mathrm{mg}$ liver tissue) generally provided about $20 \mu \mathrm{g}$ of DNA, which suffices to perform the Southern blot technique correctly. Nevertheless some samples, smaller than usual, provided less than $10 \mu \mathrm{g}$ of DNA. This was the case in patients $9,12-14,23$, and 38. Some positive results were obtained with under $10 \mu \mathrm{g}$ but when quantities are so small the negative ones should be interpreted with caution.

When previously studied samples displayed Hind III restriction liver DNA patterns, they were of one of three types: ${ }^{59}(1)$ the first was characterised by a band in the 3.2 kilobase pair position - that is, the cloned HBV DNA position - with a smear below it, this pattern corresponded to free cellular HBV DNA and to intermediate replicative forms of viral DNA, (2) the second was characterised by discrete bands located above the 3.2 kilobase pair position, corresponding to HBV DNA sequences integrated into the liver cell genome, and (3) the third pattern was a combination of the two others and indicated the presence of both free and integrated viral DNA.

The age of our present groups of children presenting with such patterns varied from five months to 15 years and the duration of their disease, from two months to six years. 
HBSAG-POSITIVE CHILDREN (GROUP I)

When suitable tissue was available for testing, $\mathrm{HBsAg}$ and $\mathrm{HBcAg}$ were always detected in the liver of these patients (Fig. 1).

In patients 1 to 12 , the Hind III liver DNA patterns always showed a band in the 3.2 kilobase pair position with, in all patients but one (12), a long smear below this position. In four of these children, additional bands corresponding to high molecular weight DNA fragments were observed. (Representative cases of this pattern are shown in Fig. 2.)

Except for patient 12, all these patients also had free viral DNA in the serum, concomitantly with HBeAg. Because of the presence of HBV DNA in the serum of patient 13 , the absence of viral DNA in his liver could be considered a false negative result, especially as the amount of DNA extracted was very low (less than $6 \mu \mathrm{g}$ ) and as he also had HBsAg and $\mathrm{HBeAg}$ in the serum and HBV antigens in the liver.

No hybridisation pattern could be found either in the liver or in the serum of patients 14 and 15 , no $\mathrm{HBeAg}$ was detected in their serums either.

All the children in group I had chronic hepatitis but no clear cut relationship could be established between hybridisation and histological patterns, especially in the cases of chronic active or chronic persistent hepatitis.

Furthermore, integrated HBV DNA sequences were found in some children with recent $\mathrm{HBV}$ infection.

\section{HBSAG-NEGATIVE CHILDREN (GROUPS IIA AND IIB)}

In group IIa, three children (patients 16-18) had fatal hepatic failure with a fulminant course in two cases, patients 16 and 17 . Patient 16 has been previously reported ${ }^{5}$ and considered as an acute hepatitis but, like patient 17 , he died within two months from hepatic failure. At the clearly apparent onset of their disease, $\mathrm{HBsAg}$ was only detected in the serum of patients 18 and afterwards disappeared. At the time of the biopsy, anti-HBc was present in the three patients' serum with, in addition, anti-HBs in patients 16 . In patient 17 , anti-HBc appeared late in the disease and was subsequently replaced by anti-HBe. In patient 18 , anti-HBc persisted from biopsy onwards and this child eventually died six months after the onset of disease. A liver test for $\mathrm{HBsAg}$ and $\mathrm{HBcAg}$ using the immunoperoxidase technique was only practicable in patient 16 and its result was negative. No HBV DNA hybridisation pattern was found in the serum of any of these children. Conversely, they all had integrated HBV DNA sequences in their Hind III liver DNA patterns. In addition, the

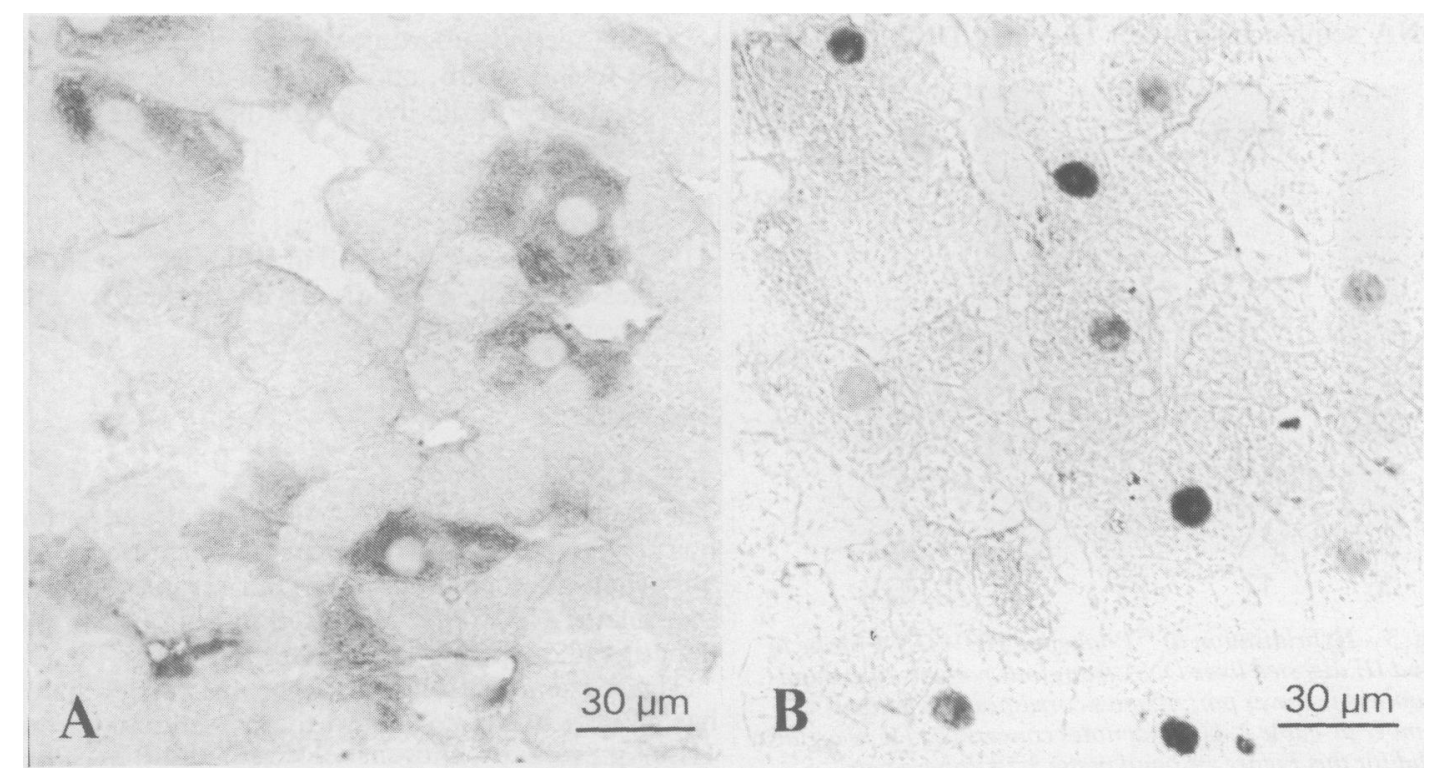

Fig. 1 Immunohistochemical demonstration of $\mathrm{HBs} \mathrm{Ag}$ and $\mathrm{HBcAg}$ in liver biopsies from patients of group I. Antigens are identified as dark brown reaction in some hepatocytes: $A-H B s A g$ in the cytoplasm (patient no 2),

$B-H B c A g$ in the nuclei (patient no 4). ( $\times 400$, original magnification.) Immunoperoxidase staining. 


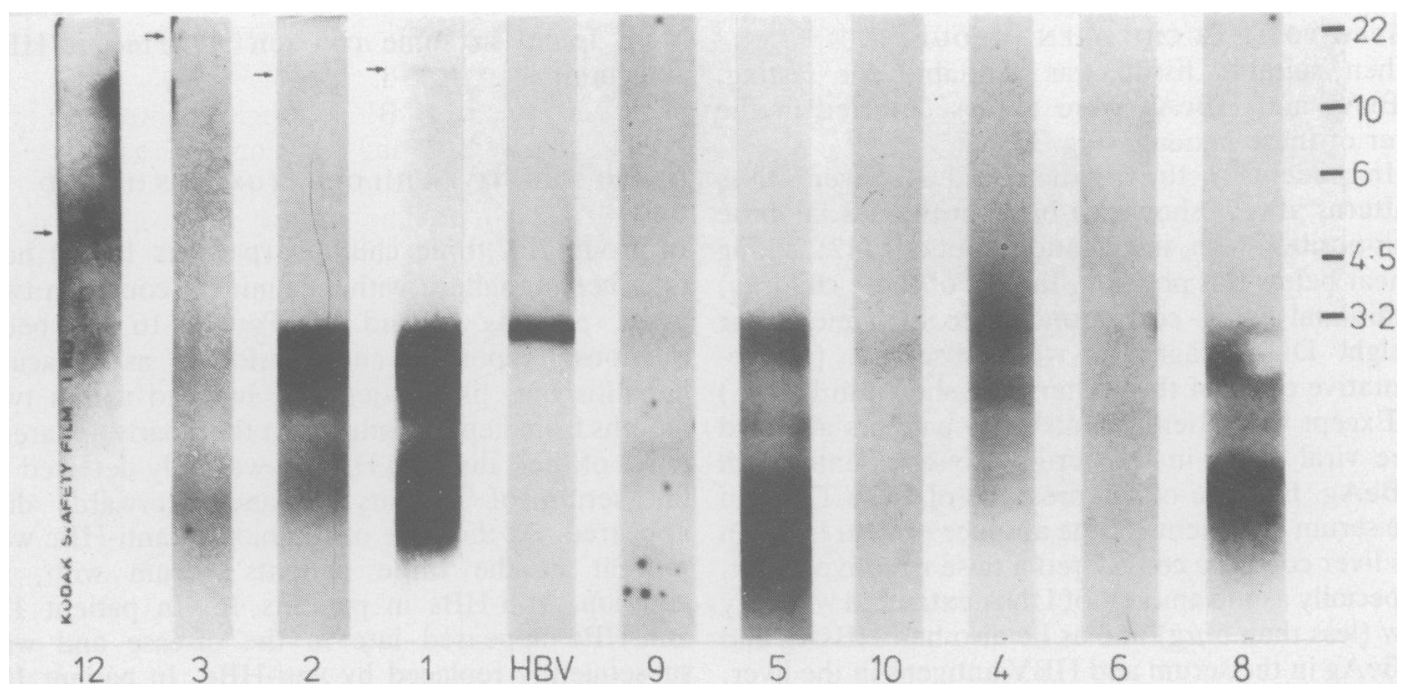

Fig. 2 Hybridisation of ${ }^{32}$ P-labelled HBV DNA probe to Hind III digested liver DNA from 10 patients of group I. The lanes are composites from different blots. In each blot cloned $H B V D N A$ was used as internal standard and the migration of Hind III digested $\lambda$ plac $5 \mathrm{c}$ I 857S7 permitted to calculate the scale expressed in kilobase pair. Intensities of signals in $3 \cdot 2$ kilobase pair position and below varied from one sample to another. Discrete bands, clearly visible only on original autoradiographs, were located in high molecular weight DNA position in liver specimens of four patients (arrows). Numbers in lower part of the lanes correspond to patients' numbers in Table 1.

pattern of patient 16 showed the presence of free viral DNA in the liver.

Three other children in this subgroup (IIa), all without anti-HBV antibodies but two with a history of HBV, presented also with only integrated HBV DNA sequences in their liver cell DNA. Two had

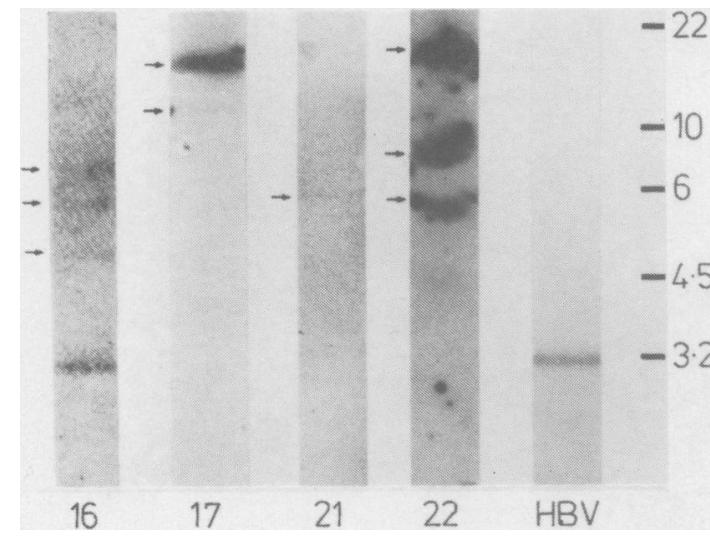

Fig. 3 Hybridisation of ${ }^{32} P$-labelled $H B V D N A$ probe to Hind III digested liver DNA from four patients of group II. Numbers in lower part of lanes correspond to patients' number in Table 2. General notes concerning Fig. 2 are also valid for this Figure. A band in the 3.2 kilobase pair position was visible only on the lane of patient no 16. Hybridisation occurred in the highest molecular weight liver DNA of all the patients (arrows). chronic active hepatitis (patients 21 and 22) and the third, inactive cirrhosis (patient 23). (Representative cases of subgroup IIa are shown in Fig. 3.)

No hybridisation was observed in all the remaining patients of this subgroup.

In the second subgroup (IIb), no HBV DNA was found in the serum, and no HBV DNA sequences were detected in the liver, regardless of the type of liver disease.

\section{CONTROL SUBJECTS (GROUP III)}

HBV DNA was not detected in either liver or serum samples from these children with normal liver or liver dysplasia at histology.

\section{Discussion}

The detection of HBV DNA in the liver and serum has both basic and clinical implications. An important point emerging from our results concerns the time of HBV DNA integration both in chronic hepatitis and in fatal hepatic failure.

The existence of two HBV chronic carrier states has already been shown. ${ }^{9}$ In the present study, the HBeAg-positive children belong to the first state, characterised by active viral multiplication in the liver. In at least some of these cases, our results show that integrated HBV DNA sequences are 
already present during the very first months or years of the disease.

In some subjects, integration appears alone, a phenomenon which defines the second HBV chronic carrier state. The latter condition, already shown in HBsAg-positive patients, ${ }^{9}$ can be extended to HBsAg-negative cases, such as those in our group IIb.

Patient 12 exhibited an uncommon pattern characterised by the absence of HBV DNA in the serum and by the absence of a long smear below the 3.2 kilobase pair position, which was considered to reflect intermediate form of DNA during active viral multiplication in the liver. ${ }^{5}$ Thus this case was considered as intermediate between the two chronic carrier states mentioned above. The absence of a long smear may be related to a decreased viral multiplication with an amount of viral particles released into the serum which was probably below the HBV DNA detection concentration. The presence of $\mathrm{HBeAg}$ which has been shown to be part of $\mathrm{HBcAg}^{14}{ }^{15}$ might either have been because of the release of empty capsids or to the expression of the corresponding integrated HBV DNA sequences. All these explanations call for further investigation.

Although non A-non B hepatitis cannot be excluded in patients totally seronegative for HBV markers, the HBV DNA integration observed in some cases suggests that their disease may be related to HBV. Thus, HBV DNA hybridisation appears especially important in diagnosis. Its usefulness is enhanced in cases where neither past antigenaemia nor any notion of HBV contagion can be found. Such a condition was evidenced in patient 21 , whose familial contagion was detected after the result of the hybridisation test was known, and in patient 22 , whose post-transfusion hepatitis had never been serologically related to HBV. Conversely, because of the negative hybridisation results observed in patients with autoimmune hepatitis, it seems unlikely that $\mathrm{HBV}$ is concerned in the pathogenesis of this kind of chronic active hepatitis.

Integrated HBV DNA sequences in the Hind III liver DNA pattern has already been found in totally seronegative patients with inactive cirrhosis. ${ }^{5}$ Our series included one case of inactive cirrhosis, however, and two others of chronic active hepatitis displaying a Hind III pattern. This suggests that integration of HBV DNA alone is not always associated with an inactive liver disease.

The three children who developed fatal hepatic failure also proved of interest in clarifying the time of integration, as the latter obviously occurred less than two or four months after the clear onset of their disease. Furthermore one of them was a five months old child in whom an earlier HBV carrier state can be certainly excluded.

In addition, the HBV serological patterns of these three patients raise the question of the relationship between the immune response and the state of $\mathrm{HBV}$ DNA. In general, the severity of liver damage in fulminant cases of hepatitis does not seem to be directly related to the degree of viral multiplication. ${ }^{16}$ One explanation suggested for massive hepatocellular necrosis is the destruction of a large number of infected hepatocytes by immune mechanisms. In the connection, the occurrence of an early enhanced humoral antibody response was stressed in contrast with the late outcome of the same humoral pattern during recovery in selflimited acute hepatitis. ${ }^{17-19}$ Cell-mediated immunity is also a probable factor determining the clinical course of HBV infection. ${ }^{20}$

Integrated sequences were found in all our three hepatic failure cases. Free viral DNA and therefore viral multiplication was absent in two of them. It was present in the third child, but in this patient the absence of HBsAg in the liver and of HBV DNA in the serum suggests that viral multiplication was decreasing, and may even have recently stopped.

It thus appears that in these severe cases, the host immune factors are better able to rapidly destroy cells where replication is taking place, than cells containing only HBV DNA sequences integrated into their genome. Whatever the cause of cellular necrosis, the persistence of cells with integrated sequences alone implies that in these cells, either viral multiplication has spontaneously resolved or integration has occurred independently of viral multiplication.

Furthermore, in these three children as well as in patients with chronic hepatitis, the presence of discrete bands in the Hind III integration patterns could be explained by the existence of preterential sites in the host genome for HBV DNA integration. ${ }^{5}$

The exact role of the remaining integrated HBV DNA sequences and of their integration sites in the outcome of the disease remains to be investigated. The present results indicate that the integration of HBV DNA sequences into the host cellular genome is an early event which might occur as soon as two months after the onset of hepatitis $B$, and is consequently not related to the duration of viral multiplication.

This study also shows that integrated HBV DNA could be the only remaining marker of HBV infection, even in the presence of an active liver disease.

Finally, it should be remembered that integration in adults was previously shown to be a potential 
factor in the development of hepatocellular carcinoma. ${ }^{12}$ It remains to be proven that integration occurring in childhood may persist and may also be such a factor.

We thank Drs B Descos, P Hadchouel, G Huault, A Leblanc, G Maggiore, and J Valayer for liver samples. This work was supported by grants from the Institut National de la Santé et de la Recherche Médicale (CRL 817.027) and the Unité d'Enseignement et de Recherche, Kremlin-Bicêtre, Université Paris-Sud (CR 826).

\section{References}

1 Bréchot C, Pourcel C, Louise A, Rain B, Tiollais P. Presence of integrated hepatitis $B$ virus DNA sequences in cellular DNA of human hepatocellular carcinoma. Nature 1980; 286: 533-5.

2 Shafritz DA, Kew MC. Identification of integrated hepatitis B virus DNA sequences in human hepatocellular carcinomas. Hepatology 1981; 1: 1-8.

3 Chakzaborty PR, Ruiz-Opazo N, Shouval D, Shafritz DA. Identification of integrated hepatitis B virus DNA and expression of viral RNA in HBsAg-producing human hepatocellular carcinoma cell line. Nature 1980 ; 286: 531-3.

4 Edman JC, Gray P, Valenzuela P, Rall LB, Rutter WJ. Integration of hepatitis $B$ virus sequences and their expression in a human hepatoma cell. Nature 1980; 286: 535-8.

5 Bréchot C, Hadchouel M, Scotto J et al. State of hepatitis B virus. DNA in hepatocytes of patients with hepatitis B surface antigen-positive and -negative liver diseases. Proc Natl Acad Sci USA 1981; 78: 3906-10.

6 Shafritz DA, Shouval D, Sherman HI, Hadziyannis SJ, Kew MC. Integration of hepatitis B virus DNA into the genome of liver cells in chronic liver disease and hepatocellular carcinoma. $N$ Engl J Med 1981; 305: 1067-73.

7 Bernard O, Hadchouel M, Scotto J, Odièvre M, Alagille D. Severe giant cell hepatitis with autoimmune hemolytic anemia in early childhood. J Pediatr 1981; 99: 704-11.

8 Bréchot C, Trepo C, Ninova-Bradistilova D et al. Hepatitis B core antigen in hepatocytes of patients with chronic active hepatitis. Dig Dis Sci 1980; 25: 593-6.

9 Bréchot C, Hadchouel M, Scotto J et al. Detection of hepatitis B virus DNA in liver and serum: a direct appraisal of the chronic carrier state. Lancet 1981; 2: $765-8$.

10 Tiollais P, Charnay P, Vyas GN. Biology of hepatitis B virus. Science 1981; 213: 406-11.

11 Southern EM. Detection of specific sequences among DNA fragments separated by gel electrophoresis. $J$ Mol Biol 1975; 98: 503-17.

12 Charnay P, Pourcel C, Louise A, Fritsch A, Tiollais P. Cloning in Escherichia Coli and physical structure of hepatitis B virion DNA. Proc Natl Acad Sci USA 1979; 76: $2222-6$.

13 Weinstock R, Sweet R, Weiss M, Cedar H, Axel R. Intragenic DNA spacers interrupt the ovalbumin gene. Proc Natl Acad Sci USA 1978; 75: 1299-303.

14 Takahashi K, Akahane Y, Gotanda T et al. Demonstration of hepatitis $\mathrm{Be}$ antigen in the core of Dane particles. J Immunol 1979; 122: 275-9.

15 Budkowska A, Kalinowska B, Nowoslawski A. Identification of two $\mathrm{HBeAg}$ subspecificities revealed by chemical treatment and enzymatic digestion of liver-derived HBcAg. J Immunol 1979; 123: 1415-6.

16 Alberti A, Diana S, Eddleston ALWF, Williams R. Changes in hepatitis $B$ virus DNA polymerase in relation to the outcome of acute hepatitis B. Gut 1979; 20: $190-5$.

17 Woolf I, El Sheikh N, Cullens H et al. Enhanced production in pathogenesis of fulminant viral hepatitis type B. Br Med J 1976; 2: 669-71.

18 Trepo CG, Robert D, Motin J, Sepetijian M, Prince AM. Hepatitis B antigen (HBsAg) and/or antibodies (anti-HBS and anti-HBc) in fulminant hepatitis: pathogenic and prognostic significance. Gut 1976; 17: 10-13.

19 Hoofnagle JH, Seeff LB, Bales ZB, Gerety RJ, Tabor D. Serological responses in HB. In: Vyas GN, Cohen SN, Schmidt R, eds. Viral hepatitis. Philadelphia: Franklin Institute Press, 1978: 219-42.

20 Dudley FJ, Fox RA, Sherlock S. Cellular immunity in hepatitis associated Australia antigen disease. Lancet 1972; 1: 723-6. 
Riemann, Dept of Internal Medicine, University of Erlangen - Nuremberg, Krankenhausstrasse 12, D-8520, Erlangen, W Germany.

10th Meeting of the European-Mediterranean Association of Colo-Proctology

This meeting will take place in Oslo from 14-16 June 1984. Main topics are Crohn's disease of the colon, colonic polyps, and anal incontinence. Free lectures of eight minutes' presentation and seven minutes' discussion are invited. Abstracts of 250 words should be submitted by 15 April 1984. Further details from the General Secretary, Dr M Parturier Albot, 25 Quai André-Citroen, Eugéne Flachat, 75017 Paris, France.

German Society for Digestive and Nutritive Illnesses The Society will award the C A Ewald-Prize for outstanding treatise in the field of pathogenesis of the peptic ulcer. The treatise may be unpublished or accepted for publication or have been already published by a scientific magazine in 1983/1984. The treatise must be in German or English. The entry should comprise: five copies of the treatise, a curriculum vitae with detailed information about scientific activities to date, and evidence of work previously published. The prize of DM 10000 will be awarded to a scientist under 40 years of age.
Please send entries before 30 April 1984 to: Herrn Prof Dr W Creutzfeld, Direktor der Medizinischen Universitätsklinik, Humboldtallee 1, D-3400 Göttingen, West Germany.

\section{9th International Cytic Fibrosis Congress}

This congress will take place in Brighton, England from 9-15 June 1984. Further information from Cystic Fibrosis Research Trust, Alexandra House, 5 Blyth Road, Bromley, Kent BR1 3RS.

\section{Indian Journal of Gastroenterology}

We are pleased to announce that the Indian Society of Gastroenterology has started publishing the above journal and we would like to wish them every success with this new venture. Further details from Dr F P Antia, Bombay Mutual Terrace, 534 Sandhurst Bridge, Bombay 400007, India.

\section{Correction}

Hepatitis B virus DNA in children's liver diseases, detection by blot hybridisation in liver and serum. $\mathbf{J}$ Scotto, Michelle Hadchouel, Christiane Hery et al. (July issue, Gut 24: 618-24.) Table 2 in this paper had incorrectly set headings and a corrected version is printed below.

Table 2 Group II: hepatitis B surface antigen-negative children

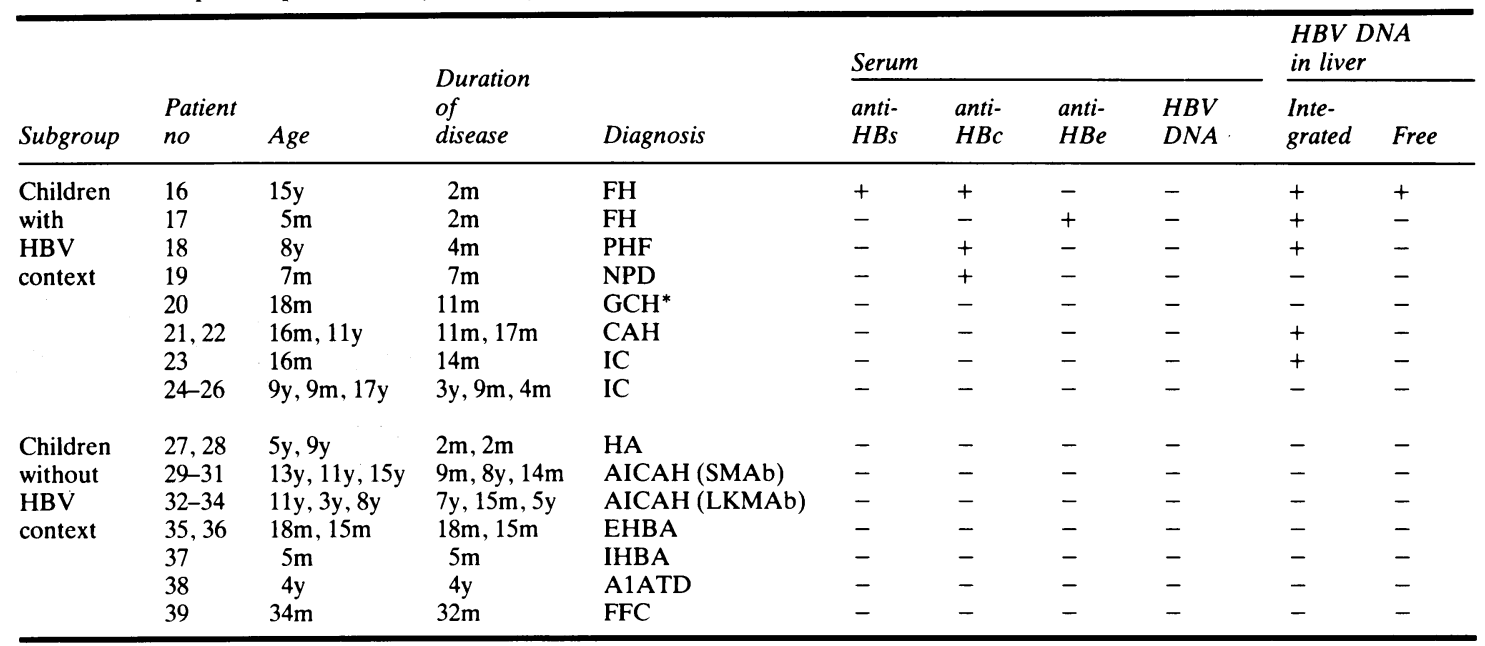

FH = fulminant hepatitis; PHF = progressive hepatic failure; NPD = Niemann Pick disease; $\mathrm{GCH}=$ giant cell hepatitis;

$\mathrm{CAH}=$ chronic active hepatitis; IC = inactive cirrhosis; $\mathrm{HA}=$ hepatitis $\mathrm{A} ; \mathrm{AICAH}=$ autoimmune chronic active hepatitis;

$\mathrm{SMAb}=$ smooth muscle antibodies; LKMAb = liver kidney microsomal antibodies; EHBA = extrahepatic biliary atresia;

IHBA = intrahepatic biliary atresia; A1ATD = alpha-1-antitrypsin deficiency; FFC = familial fibrogenic cholestasis; anti-

$\mathrm{HBs}=$ antibody to hepatitis $\mathrm{B}$ surface antigen; anti-HBc $=$ antibody to hepatitis $\mathrm{B}$ core antigen; anti-HBe = antibody to hepatitis Be antigen.

${ }^{*}$ Giant cell hepatitis with autoimmune haemolytic anaemia. ${ }^{7}$ 